\title{
Effect of Storage Temperature on Physico-Chemical and Sensory Evaluation of Kinnow Mandarin Juice Blends
}

Bhardwaj RL* and Urvashi Nandal

Maharana Pratap University of Agriculture and Technology, Udaipur (Rajasthan), India

\begin{abstract}
The present investigation comprises 20 treatment combinations having five different combinations of Kinnow juice blends, two processing temperature $\left(75^{\circ} \mathrm{C}\right.$ and $\left.85^{\circ} \mathrm{C}\right)$ and two levels of potassium meta-bi-sulphite $(500 \mathrm{ppm}$ and $750 \mathrm{ppm})$. The juice blend combinations thus prepared were stored for six months in $200 \mathrm{ml}$ glass bottles at refrigerated storage temperature $(4 \pm$ $1^{\circ} \mathrm{C}$ ) and at ambient temperature $\left(28 \pm 4^{\circ} \mathrm{C}\right)$. Juice blending ratio (Kinnow juice 87: Pomegranate juice 10: Ginger juice 3 ) with processing temperature $\left(75^{\circ} \mathrm{C}\right.$ for 15 minutes $)$ and potassium meta-bi-sulphite $(750 \mathrm{ppm})$ showed better qualitative characteristics i.e. T.S.S., acidity, ascorbic acid, total sugars, NEB, limonin, flavour, colour and bitterness during storage (up to six months) under refrigeration and ambient temperature. However, the post storage studies also revealed that all these characteristics were superior under refrigerated condition than ambient storage conditions. There was minimum increase in TSS (11.88 to $\left.13.21^{\circ} \mathrm{Brix}\right)$, total sugar $(7.88 \%$ to $9.60 \%)$, limonin $\left(0.116 \mathrm{mg} \mathrm{ml}^{-1}\right.$ to $\left.0.138 \mathrm{mg} \mathrm{ml}^{-1}\right)$, NEB $(0.065$ to 0.081$)$ and the lowest decrease was observed

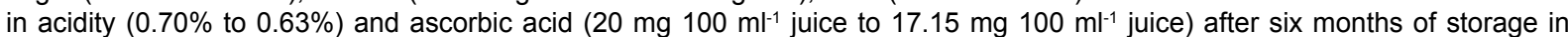
refrigerated condition. From economic point of view maximum B.C. ratio $(1.5: 1)$ was obtained by making squash from the juice blend (Kinnow juice 87: Pomegranate juice 10: ginger juice3) + processed at $75^{\circ} \mathrm{C}+\mathrm{KMS}(750 \mathrm{ppm})$ and stored under refrigerated temperature
\end{abstract}

Keywords: Kinnow juice; Juice blends; Ambient condition; Physicochemical properties; Organoleptic score; Non-enzymatic browning

\section{Introduction}

Among citrus group Kinnow is an important mandarin hybrid (Citrus nobilis $x$ C. deliciosa) suited to North Indian conditions. Mandarins are extensively grown throughout India, particularly in the states of Punjab, Haryana, Maharashtra, Assam, Karnataka, and Andhra Pradesh. The area under Kinnow mandarin in Rajasthan is 8,290 hectares and production is 157,460 metric tonnes with 19.0 metric tonnes productivity (Indian Horticulture Database, 2012) [1]. Kinnow mandarin is quite important as it has a great variety of beverage, industrial and medicinal uses due to its attractive colour, distinctive flavour and being rich source of vitamin $C$, vitamin $B, \beta$-carotene, calcium and phosphorous [2]. Kinnow mandarin juice turns bitter after extraction due to conversion of limonate-a-ring-lactone (non-bitter) to limonin (bitter compound) during storage [3], and makes limited processing of this fruit. For improving the taste, aroma, palatability, nutritive value and reducing bitterness kinnow juice was blended with some other highly nutritive fruit juices namely pomegranate and Aonla juice with spice extracts like ginger. The post-harvest shelf life of fruit at room temperature is very limited and shelf life can be extended to a maximum period up to 45 days under refrigerated storage temperature [4]. In view of its limited shelf life (10 days) under ambient condition, the fruit must be processed to extend its availability period and also to minimize the glut in the market during its peak season of production. Kinnow juice turns bitter during extraction and heat processing and is not liked much by majority of consumers. To popularize kinnow juice among masses, it is necessary to develop suitable technology, which should be commercially feasible to process this highly nutritious fruit. Among various preservation techniques for extending the storage life of fruit juice with high sensory attributes is the use of refrigeration chamber. Prasad and Mali [5], Bhardwaj and Mukherjee [4] have reported that the fruit juice stored at low temperature (4 \pm $1^{\circ} \mathrm{C}$ ) maintained good natural colour and organoleptic quality with minimum microbial growth. The present investigation was undertaken to study the effect of storage conditions on the physico-chemical and organoleptic qualities of Kinnow juice after storage.

\section{Materials and Methods}

The fully matured, disease free Kinnow mandarin, pomegranate, aonla and ginger were procured from the local market and brought to the Post Harvest Technology laboratory at SKN College of Agriculture Jobner for further studies. The fruits were thoroughly washed with running water to remove dirt, dust particles and insecticidal residues, dried properly under shade. Kinnow were peeled manually and the juice was obtained using screw type juice extractor machine. The fully ripe pomegranate were cut in to pieces and arils were separated. These arils were passed through the juice extractor for extraction of juice. Aonla and ginger were sliced with help of stainless steel knives and crushed with mixer cum juicer for the extraction of juice. After extraction these juices were kept in cold room $\left(4 \pm 1^{\circ} \mathrm{C}\right)$ immediately. The Kinnow juice was filtered through muslin cloth and divided into lots and other fruit juices were mixed as per various blending ratios. Each lot was divided into 2 sub lots and heated separately at $75^{\circ} \mathrm{C}$ and $85^{\circ} \mathrm{C}$ for 15 minutes, respectively in a double jacked stainless steel kettle. Again each sub-lot was divided into two lots. A calculated quantity of potassium meta-bisulphite (500 and $750 \mathrm{ppm}$ ) was mixed. Treated juice was filled in presterilized $200 \mathrm{ml}$ capacity bottles as soon as possible and then tightly closed using crown corking machine. The bottles containing juice were

*Corresponding author: Bhardwaj RL, (Horticulturist), Maharana Pratap University of Agriculture and Technology, Post Box. 15, Krishi Vigyan Kendra - Sirohi (Rajasthan) India 307001, Tel: 09414932949; E-mail: rajubhardwaj3@gmail.com

Received May 02, 2014; Accepted August 26, 2014; Published September 03 2014

Citation: Bhardwaj RL, Nandal U (2014) Effect of Storage Temperature on Physico-Chemical and Sensory Evaluation of Kinnow Mandarin Juice Blends. J Food Process Technol 5: 361. doi:10.4172/2157-7110.1000361

Copyright: (C) 2014 Bhardwaj RL, et al. This is an open-access article distributed under the terms of the Creative Commons Attribution License, which permits unrestricted use, distribution, and reproduction in any medium, provided the original author and source are credited. 
stored at refrigerated temperature $\left(4 \pm 1^{\circ} \mathrm{C}\right)$ and ambient temperature $\left(28 \pm 4^{\circ} \mathrm{C}\right)$ condition for further storage studies. Samples were taken in duplicate at one month interval for six months. The physico- chemical parameters including total soluble solids, total sugars, titratable acidity (as citric acid) and ascorbic acid were determined by A.O.A.C. (1984) methods and limonin of the juice was estimated using the modified Buruliam reagent [6] method. The non- enzymatic browning in the juice was determined by alcohol extraction method [7]. Juice was studied on a 9 point hedonic scale in order to find out the consumer preference for juice blend ratio in terms of organoleptic quality [8]. The organoleptic panel consisted of ten semi-trained panelists. All estimations were carried out in triplicate. Determinations were made for each attribute and data pertaining to the physico-chemical and sensory scores were analyzed using factorial Completely Randomized Design [9].

\section{Results and Discussion}

\section{Effect on physico - chemical properties}

The changes observed in the physico-chemical constituents of Kinnow juice blend at ambient and refrigerated temperature during storage period are given in Tables 1-4. The data was collected at one month interval for each parameter. But for discussion, only observations of the first and last month of storage have been taken. The results showed that TSS and total sugars content was significantly affected with passage of time during storage. The cause of higher increase in TSS and total sugars content in these juice blends stored at ambient condition, might be due to higher rate of solubilization. Another possible explanation of increased TSS and total sugars may be the conversion of acids in to sugars. Minimum increase in total soluble solids and total sugars under refrigerated storage might be due to low temperature, thus reducing hydrolysis of poly-saccharides and acids. Similar results were also reported by Prasad and Mali [5] in Kinnow juice, Deka [10] in juice blends, Singh and Mathur [11] in cashew apple juice, Bhardwaj and Mukherjee [4] in kinnow juice. A perusal of data (Tables 1-4) revealed that acidity and ascorbic acid content of the stored juice decreased due to oxidation as the period of storage advanced. It has been reported that ascorbic acid is very sensitive to oxidation and converted to dehydroascorbic acid by the enzyme ascorbinase [12]. But the decrease was lower under refrigerated storage condition which may be attributed to low temperature and high relative humidity in storage, which inhibited the conversion of acid in sugars and decreased rate of ascorbic acid oxidation. These results are supported by the findings of Singh and Mathur [11] in cashew apples and Sethi et al. [13] in Kinnow juice.

A gradual increase in limonin in juice blends with advancing storage period might be due to conversion of a chemical compound limonate-a-ring lactone (non-bitter) in to limonin (bitter) in the juice [3]. The juice kept in refrigerated storage recorded less increase in limonin as compared to the juice kept under ambient condition. This might be due to fact that the juice kept in former condition experienced slower rate of conversion and thus increase in limonin content of juice was less. Similar findings have been reported by Sogi and Singh [2] in Kinnow juice. Gradual browning of juice was observed with advancing storage period at both storage conditions which might be due to the enzymatic and non- enzymatic reactions in the juice. But in refrigerated storage, browning was arrested due to low temperature which declined the enzymatic and non-enzymatic reactions of the juice during storage. Similar results were also reported by Khurdiya and Anand [14] in phalsa beverage, Bhardwaj and Mukherjee [4] in kinnow juice.

\section{Sensory evaluation}

In the present study, results indicated that flavour, colour and bitterness score of juice blends, decreased with advancement of storage period (Tables 1-4) under both storage conditions. But decreasing rate

\begin{tabular}{|c|c|c|c|c|c|c|c|c|c|}
\hline Treatments & $\begin{array}{l}\text { TSS } \\
\text { ('Brix) }\end{array}$ & Total sugar (\%) & $\begin{array}{l}\text { Acidity } \\
(\%)\end{array}$ & $\begin{array}{l}\text { Ascorbic } \\
\text { acid (mg.100 } \\
\mathrm{ml})\end{array}$ & $\begin{array}{l}\text { Limonin } \\
\text { (mg/ml. juice }\end{array}$ & $\begin{array}{l}\text { NEB } \\
(640 \mathrm{~nm})\end{array}$ & $\begin{array}{l}\text { Flavour } \\
\text { (10 mark) }\end{array}$ & $\begin{array}{l}\text { Colour } \\
\text { (10 mark) }\end{array}$ & $\begin{array}{l}\text { Bitterness } \\
\text { (10 mark) }\end{array}$ \\
\hline \multicolumn{10}{|l|}{ Juice blend } \\
\hline $\mathrm{K}_{1}$ & 10.79 & 7.75 & 0.73 & 21.34 & 0.230 & 0.080 & 8.52 & 8.74 & 7.78 \\
\hline $\mathrm{K}_{2}$ & 10.13 & 7.75 & 0.78 & 46.15 & 0.174 & 0.086 & 8.14 & 8.62 & 8.18 \\
\hline $\mathrm{K}_{3}$ & 10.04 & 7.66 & 0.78 & 45.92 & 0.162 & 0.083 & 8.23 & 8.65 & 8.41 \\
\hline $\mathrm{K}_{4}$ & 11.63 & 8.55 & 0.72 & 19.79 & 0.140 & 0.070 & 9.29 & 9.28 & 8.90 \\
\hline $\mathrm{K}_{5}$ & 10.96 & 8.39 & 0.70 & 18.99 & 0.126 & 0.066 & 9.61 & 9.22 & 9.15 \\
\hline S Em. \pm & 0.151 & 0.109 & 0.009 & 0.471 & 0.002 & 0.001 & 0.047 & 0.126 & 0.041 \\
\hline CD at $5 \%$ & 0.433 & 0.311 & 0.026 & 1.347 & 0.004 & 0.003 & 0.135 & 0.361 & 0.119 \\
\hline \multicolumn{10}{|c|}{ Temperature } \\
\hline $\mathrm{T}_{1}$ & 10.42 & 8.16 & 0.76 & 30.88 & 0.149 & 0.080 & 8.84 & 9.24 & 8.44 \\
\hline $\mathrm{T}_{2}$ & 11.00 & 7.88 & 0.72 & 29.99 & 0.185 & 0.074 & 8.68 & 8.57 & 8.54 \\
\hline S Em. \pm & 0.096 & 0.069 & 0.006 & 0.298 & 0.001 & 0.001 & 0.030 & 0.080 & 0.026 \\
\hline CD at $5 \%$ & 0.274 & 0.197 & 0.010 & 0.852 & 0.004 & 0.002 & 0.085 & 0.229 & 0.075 \\
\hline \multicolumn{10}{|l|}{ KMS } \\
\hline$P_{1}$ & 10.75 & 8.17 & 0.73 & 30.35 & 0.171 & 0.078 & 8.71 & 8.75 & 8.44 \\
\hline $\mathrm{P}_{2}$ & 10.67 & 7.86 & 0.75 & 30.52 & 0.163 & 0.076 & 8.80 & 9.06 & 8.54 \\
\hline S Em. \pm & 0.096 & 0.069 & 0.006 & 0.298 & 0.003 & 0.001 & 0.030 & 0.080 & 0.026 \\
\hline CD at $5 \%$ & NS & 0.197 & 0.016 & NS & 0.004 & 0.002 & 0.085 & 0.229 & 0.075 \\
\hline
\end{tabular}

$\mathrm{K}=$ Kinnow juice $(100 \%)$

$\mathrm{K}_{2}=$ Kinnow juice $(95 \%)+$ Aonla $(5 \%)$

$\mathrm{K}_{3}^{2}=$ Kinnow juice $(92 \%)+$ Aonla $(5 \%)+$ Ginger $(3 \%)$

$\mathrm{K}_{4}=$ Kinnow juice $(90 \%)+$ Pomegranate $(10 \%)$

$\mathrm{K}_{5}=$ Kinnow juice $(87 \%)+$ Pomegranate $(10 \%)+$ Ginger $(3 \%)$

Table 1: Effect of storage temperature (ambient conditions) on physico-chemical and sensory scores of Kinnow juice after Ist month of storage
N.S. $=$ Non- significant

$\mathrm{T}_{1}=$ Processing at $75^{\circ}$ for 15 minutes

$\mathrm{T}_{2}=$ Processing at $85^{\circ}$ for 15 minutes

$\mathrm{P}_{1}=\mathrm{KMS} 500 \mathrm{ppm}$

$\mathrm{P}_{2}=\mathrm{KMS} 750 \mathrm{ppm}$ 
Citation: Bhardwaj RL, Nandal U (2014) Effect of Storage Temperature on Physico-Chemical and Sensory Evaluation of Kinnow Mandarin Juice Blends. J Food Process Technol 5: 361. doi:10.4172/2157-7110.1000361

Page 3 of 4

\begin{tabular}{|c|c|c|c|c|c|c|c|c|c|}
\hline Treatments & $\begin{array}{l}\text { TSS } \\
\text { ('Brix) }\end{array}$ & Total sugar (\%) & $\begin{array}{l}\text { Acidity } \\
(\%)\end{array}$ & $\begin{array}{l}\text { Ascorbic } \\
\text { acid }(\mathrm{mg} .100 \mathrm{ml})\end{array}$ & $\begin{array}{l}\text { Limonin } \\
\text { (mg/ml. juice) }\end{array}$ & $\begin{array}{l}\text { NEB } \\
(640 \mathrm{~nm})\end{array}$ & $\begin{array}{l}\text { Flavour } \\
\text { (10 mark) }\end{array}$ & $\begin{array}{l}\text { Colour } \\
\text { (10 mark) }\end{array}$ & $\begin{array}{l}\text { Bitterness } \\
\text { (10 mark) }\end{array}$ \\
\hline \multicolumn{10}{|l|}{ Juice blend } \\
\hline $\mathrm{K}_{1}$ & 11.58 & 7.25 & 0.72 & 22.75 & 0.213 & 0.082 & 8.71 & 8.85 & 8.33 \\
\hline $\mathrm{K}_{2}$ & 11.00 & 7.24 & 0.77 & 47.15 & 0.159 & 0.088 & 8.25 & 8.65 & 8.72 \\
\hline $\mathrm{K}_{3}$ & 11.00 & 7.20 & 0.77 & 47.05 & 0.149 & 0.084 & 8.32 & 8.73 & 8.94 \\
\hline $\mathrm{K}_{4}$ & 12.50 & 8.02 & 0.69 & 20.66 & 0.128 & 0.070 & 9.41 & 9.22 & 9.36 \\
\hline $\mathrm{K}_{5}$ & 11.88 & 7.88 & 0.70 & 20.00 & 0.116 & 0.065 & 9.69 & 9.17 & 9.61 \\
\hline S Em. \pm & 0.116 & 0.062 & 0.055 & 0.484 & 0.002 & 0.001 & 0.048 & 0.110 & 0.051 \\
\hline CD at $5 \%$ & 0.333 & 0.178 & 0.015 & 1.384 & 0.005 & 0.002 & 0.136 & 0.316 & 0.146 \\
\hline \multicolumn{10}{|c|}{ Temperature } \\
\hline$T_{1}$ & 11.35 & 7.60 & 0.75 & 32.19 & 0.137 & 0.082 & 8.98 & 9.15 & 8.94 \\
\hline $\mathrm{T}_{2}$ & 11.83 & 7.44 & 0.71 & 30.85 & 0.170 & 0.073 & 8.77 & 8.69 & 9.04 \\
\hline S Em. \pm & 0.074 & 0.039 & 0.003 & 0.306 & 0.001 & 0.0003 & 0.030 & 0.070 & 0.032 \\
\hline$C D$ at $5 \%$ & 0.210 & 0.113 & 0.010 & 0.875 & 0.003 & 0.001 & 0.086 & 0.200 & 0.092 \\
\hline \multicolumn{10}{|l|}{ KMS } \\
\hline $\mathrm{P}_{1}$ & 11.62 & 7.60 & 0.72 & 31.22 & 0.155 & 0.078 & 8.83 & 8.81 & 8.93 \\
\hline $\mathrm{P}_{2}$ & 11.57 & 7.44 & 0.74 & 31.82 & 0.152 & 0.075 & 8.93 & 9.03 & 9.05 \\
\hline S Em. \pm & 0.074 & 0.039 & 0.003 & 0.306 & 0.001 & 0.0003 & 0.030 & 0.070 & 0.032 \\
\hline$C D$ at $5 \%$ & NS & 0.113 & 0.010 & NS & 0.004 & 0.001 & 0.086 & 0.200 & 0.092 \\
\hline
\end{tabular}

$\mathrm{K}_{1}=$ Kinnow juice $(100 \%)$

$\mathrm{K}_{2}=$ Kinnow juice $(95 \%)+$ Aonla $(5 \%)$

N.S.=Non- significant

$T_{1}=$ Processing at $75^{\circ}$ for 15 minutes

$\mathrm{T}_{2}=$ Processing at $85^{\circ}$ for 15 minutes

$\mathrm{P}_{1}=\mathrm{KMS} 500 \mathrm{ppm}$

$\mathrm{P}_{2}=\mathrm{KMS} 750 \mathrm{ppm}$

$\mathrm{K}_{4}=$ Kinnow juice $(90 \%)+$ Pomegranate $(10 \%)$

$\mathrm{K}_{5}=$ Kinnow juice $(87 \%)+$ Pomegranate $(10 \%)+$ Ginger $(3 \%)$

Table 2: Effect of storage temperature (refrigerated storage) on physico-chemical and sensory scores of Kinnow juice after It $^{\text {st }}$ month of storage

\begin{tabular}{|c|c|c|c|c|c|c|c|c|c|}
\hline Treatments & $\begin{array}{l}\text { TSS } \\
\text { ('Brix) }\end{array}$ & Total sugar (\%) & $\begin{array}{l}\text { Acidity } \\
(\%)\end{array}$ & $\begin{array}{l}\text { Ascorbic } \\
\text { acid (mg.100 ml) }\end{array}$ & $\begin{array}{l}\text { Limonin } \\
\text { (mg/ml. juice) }\end{array}$ & $\begin{array}{l}\text { NEB } \\
(640 \mathrm{~nm})\end{array}$ & $\begin{array}{l}\text { Flavour } \\
\text { (10 mark) }\end{array}$ & $\begin{array}{l}\text { Colour } \\
\text { (10 mark) }\end{array}$ & $\begin{array}{l}\text { Bitterness } \\
\text { (10 mark) }\end{array}$ \\
\hline \multicolumn{10}{|l|}{ Juice blend } \\
\hline $\mathrm{K}_{1}$ & 14.63 & 11.57 & 0.40 & 11.87 & 0.302 & 0.135 & 4.74 & 5.15 & 4.79 \\
\hline $\mathrm{K}_{2}$ & 13.75 & 11.47 & 0.51 & 38.39 & 0.232 & 0.138 & 4.82 & 5.30 & 5.33 \\
\hline $\mathrm{K}_{3}$ & 13.33 & 11.03 & 0.54 & 39.47 & 0.216 & 0.132 & 5.08 & 5.48 & 5.66 \\
\hline $\mathrm{K}_{4}$ & 15.21 & 12.17 & 0.41 & 12.61 & 0.188 & 0.109 & 6.61 & 6.94 & 6.85 \\
\hline $\mathrm{K}_{5}$ & 13.96 & 11.85 & 0.52 & 13.41 & 0.165 & 0.100 & 7.26 & 7.29 & 7.54 \\
\hline S Em. \pm & 0.148 & 0.138 & 0.007 & 0.430 & 0.002 & 0.001 & 0.058 & 0.079 & 0.039 \\
\hline CD at $5 \%$ & 0.423 & 0.394 & 0.019 & 1.229 & 0.004 & 0.004 & 0.165 & 0.225 & 0.113 \\
\hline \multicolumn{10}{|c|}{ Temperature } \\
\hline $\mathrm{T}_{1}$ & 13.77 & 11.96 & 0.49 & 23.78 & 0.198 & 0.131 & 5.93 & 6.11 & 5.95 \\
\hline $\mathrm{T}_{2}$ & 14.58 & 11.27 & 0.47 & 22.51 & 0.245 & 0.115 & 5.47 & 5.95 & 6.12 \\
\hline S Em. \pm & 0.094 & 0.087 & 0.004 & 0.272 & 0.001 & 0.001 & 0.037 & 0.050 & 0.025 \\
\hline CD at $5 \%$ & 0.267 & 0.249 & 0.012 & 0.778 & 0.004 & 0.003 & 0.105 & 0.142 & 0.071 \\
\hline \multicolumn{10}{|l|}{ KMS } \\
\hline$P_{1}$ & 14.32 & 11.82 & 0.46 & 22.67 & 0.232 & 0.128 & 5.47 & 5.83 & 5.96 \\
\hline $\mathrm{P}_{2}$ & 14.03 & 11.41 & 0.49 & 23.62 & 0.211 & 0.118 & 5.93 & 6.23 & 6.11 \\
\hline S Em. \pm & 0.094 & 0.087 & 0.004 & 0.272 & 0.001 & 0.001 & 0.037 & 0.050 & 0.025 \\
\hline CD at $5 \%$ & 0.267 & 0.249 & 0.012 & 0.778 & 0.004 & 0.003 & 0.105 & 0.142 & 0.071 \\
\hline
\end{tabular}

$\mathrm{K}_{1}=$ Kinnow juice $(100 \%)$

N.S.=Non- significant

$\mathrm{K}_{2}=$ Kinnow juice $(95 \%)+$ Aonla $(5 \%)$

$\mathrm{T}_{1}=$ Processing at $75^{\circ}$ for 15 minutes

$\mathrm{K}_{3}=$ Kinnow juice $(92 \%)+$ Aonla $(5 \%)+$ Ginger $(3 \%)$

$\mathrm{K}_{4}=$ Kinnow juice $(90 \%)+$ Pomegranate $(10 \%)$

$\mathrm{T}_{2}^{1}=$ Processing at $85^{\circ}$ for 15 minutes

$\mathrm{P}_{1}=$ KMS $500 \mathrm{ppm}$

$\mathrm{K}_{5}=$ Kinnow juice $(87 \%)+$ Pomegranate $(10 \%)+$ Ginger $(3 \%) \quad \mathrm{P}_{2}=\mathrm{KMS} 750 \mathrm{ppm}$

Table 3: Effect of storage temperature (ambient conditions) on physico-chemical and sensory scores of Kinnow juice after $\mathrm{V} \mathrm{I}^{\text {th }} \mathrm{month}$ of storage 
Citation: Bhardwaj RL, Nandal U (2014) Effect of Storage Temperature on Physico-Chemical and Sensory Evaluation of Kinnow Mandarin Juice Blends. J Food Process Technol 5: 361. doi:10.4172/2157-7110.1000361

Page 4 of 4

\begin{tabular}{|c|c|c|c|c|c|c|c|c|c|}
\hline Treatments & $\begin{array}{l}\text { TSS } \\
\text { ('Brix) }\end{array}$ & Total sugar (\%) & $\begin{array}{l}\text { Acidity } \\
(\%)\end{array}$ & $\begin{array}{l}\text { Ascorbic } \\
\text { acid (mg.100 } \\
\mathrm{ml})\end{array}$ & $\begin{array}{l}\text { Limonin } \\
\text { (mg/ml. juice) }\end{array}$ & $\begin{array}{l}\text { NEB } \\
(640 \mathrm{~nm})\end{array}$ & $\begin{array}{l}\text { Flavour } \\
\text { (10 mark) }\end{array}$ & $\begin{array}{l}\text { Colour } \\
\text { (10 mark) }\end{array}$ & $\begin{array}{l}\text { Bitterness } \\
\text { (10 mark) }\end{array}$ \\
\hline \multicolumn{10}{|l|}{ Juice blend } \\
\hline $\mathrm{K}_{1}$ & 13.50 & 9.13 & 0.59 & 17.89 & 0.254 & 0.108 & 7.25 & 7.11 & 6.77 \\
\hline $\mathrm{K}_{2}$ & 12.88 & 9.05 & 0.67 & 43.40 & 0.194 & 0.111 & 6.60 & 7.14 & 7.24 \\
\hline $\mathrm{K}_{3}$ & 12.50 & 8.82 & 0.68 & 43.70 & 0.179 & 0.107 & 6.71 & 7.20 & 7.52 \\
\hline $\mathrm{K}_{4}$ & 14.33 & 9.85 & 0.58 & 17.18 & 0.153 & 0.087 & 8.09 & 8.12 & 8.27 \\
\hline $\mathrm{K}_{5}$ & 13.21 & 9.60 & 0.63 & 17.15 & 0.138 & 0.081 & 8.53 & 8.33 & 8.74 \\
\hline S Em. \pm & 0.104 & 0.108 & 0.005 & 0.432 & 0.002 & 0.001 & 0.054 & 0.079 & 0.054 \\
\hline CD at $5 \%$ & 0.297 & 0.308 & 0.015 & 1.234 & 0.005 & 0.003 & 0.154 & 0.277 & 0.156 \\
\hline \multicolumn{10}{|c|}{ Temperature } \\
\hline$T_{1}$ & 12.88 & 9.43 & 0.64 & 28.47 & 0.165 & 0.105 & 7.70 & 7.72 & 7.65 \\
\hline $\mathrm{T}_{2}$ & 13.68 & 9.15 & 0.62 & 27.25 & 0.203 & 0.093 & 7.18 & 7.44 & 7.76 \\
\hline S Em. \pm & 0.066 & 0.068 & 0.003 & 0.273 & 0.001 & 0.001 & 0.034 & 0.050 & 0.034 \\
\hline$C D$ at $5 \%$ & 0.188 & 0.195 & 0.010 & 0.780 & 0.003 & 0.002 & 0.098 & 0.143 & 0.098 \\
\hline \multicolumn{10}{|l|}{ KMS } \\
\hline $\mathrm{P}_{1}$ & 13.38 & 9.39 & 0.63 & 27.46 & 0.191 & 0.102 & 7.38 & 7.45 & 7.55 \\
\hline $\mathrm{P}_{2}$ & 13.18 & 9.19 & 0.64 & 28.27 & 0.177 & 0.096 & 7.49 & 7.71 & 7.70 \\
\hline S Em. \pm & 0.066 & 0.068 & 0.003 & 0.273 & 0.001 & 0.001 & 0.034 & 0.050 & 0.034 \\
\hline $\mathrm{CD}$ at $5 \%$ & 0.188 & 0.068 & 0.010 & 0.780 & 0.003 & 0.002 & 0.098 & 0.143 & 0.098 \\
\hline
\end{tabular}

$\mathrm{K}_{1}=$ Kinnow juice $(100 \%)$

$\mathrm{K}_{2}=$ Kinnow juice $(95 \%)+$ Aonla $(5 \%)$

$\mathrm{K}_{3}=$ Kinnow juice $(92 \%)+$ Aonla $(5 \%)+$ Ginger $(3 \%)$

$\mathrm{K}_{4}=$ Kinnow juice $(90 \%)+$ Pomegranate $(10 \%)$

$\mathrm{K}_{5}=$ Kinnow juice $(87 \%)+$ Pomegranate $(10 \%)+$ Ginger $(3 \%)$

Table 4: Effect of storage temperature (refrigerated storage) on physico-chemical and sensory scores of Kinnow juice after $\mathrm{V} \mathrm{I}^{\text {th }}$ month of storage

was higher for ambient storage than the refrigerated storage condition. Possible explanation for good sensory evaluation of juice blends when kept in refrigerated storage might be due to the fact that the low temperature and high relative humidity did not cause any change in qualitative characters and palatability of stored juice and helped in maintaining juice flavour, colour and TSS: acid ratio and sugars in balanced form than the ambient storage condition. In ambient condition change in colour of Kinnow juice might be attributed to oxidation of phenolic compounds present in juice and chemical reactions apparently follow the formation of dark pigments. Similar findings were reported earlier by Khurdiya and Anand [14] in phalsa beverage, Pandey and Singh [15] in guava RTS beverage. Prasad and Mali [5] reported that the colour, flavour and taste of the pomegranate squash remained better at low temperature than at room temperature [16].

\section{Conclusion}

On the basis of results it can be concluded that the fruit juice blends can be stored effectively for a period of 6 months with minimum changes of all physico-chemical characters when fruit juice blends were stored at refrigeration temperature $\left(4 \pm 1^{\circ} \mathrm{C}\right)$. Their total soluble solids, total sugars, limonin and non- enzymatic browning increased with advancing storage but acidity, ascorbic acid and sensory quality score was reduced with advancement of storage. The juice blend (Kinnow juice $87 \%+$ Pomegranate juice $10 \%+$ Ginger juice $3 \%$ ) and followed by (Kinnow juice $92 \%+$ Aonla juice $5 \%+$ Ginger juice $3 \%$ ), processed at $75^{\circ} \mathrm{C}$ for 15 minutes with $750 \mathrm{ppm}$ potassium meta-bi-sulphite proved to be the most effective treatment for better physico-chemical qualities and sensory scores of the juice blends when stored at refrigeration temperature $\left(4 \pm 1^{\circ} \mathrm{C}\right)$. The maximum B.C. ratio (1.5: 1$)$ was obtained by making squash from the juice blend (Kinnow juice 87: Pomegranate juice 10: ginger juice 3$)+$ processed at $75^{\circ} \mathrm{C}+\mathrm{KMS}(750 \mathrm{ppm})$ and stored under refrigeration temperature $\left(4 \pm 1^{\circ} \mathrm{C}\right)$ as compared to ambient temperature $\left(28 \pm 4^{\circ} \mathrm{C}\right)$.

\section{References}

1. National Horticulture Board (2012) National Horticulture Board.

2. Sogi DS, Singh S (2001) Studies on bitterness development in Kinnow juice, ready-to-serve, beverage, squash, jam and candy. J Food Sci \& Technol 38: 433-438.

3. Premi BR, Lal BB, Joshi VK (1994) Distribution pattern of bittening principle in Kinnow fruits. J Food Sci \& Technol 31: 140-141.

4. Bhardwaj RL, Mukherjee S (2011) Effects of fruit juice blending ratios on kinnow juice preservation at ambient storage condition. African Journal of Food Science 5: 281-286.

5. Prasad RN, Mali PC (2000) Change in physico -chemical characteristics of pomegranate squash during storage. Indian J Hort 57: 18-20.

6. Vaks B, Litshitz A (1981) Debittering of orange juice by bacteria, which degrade limonin. J Agric Food Chem 29: 1258-1261.

7. Klin M, Nagy S (1988) An improved method to determine non-enzymic browning in citrus juice. J Agric Food Chem 36: 1271-1274.

8. Amerine MA, Pangbron RM, Rossler EA (1965) Principles of sensory evaluation of food. Acadamic Press, New York and London.

9. Cochran WG, Cox GM (1950) Experimental Design, Pub. John Willey Inc, New York.

10. Deka BC (2000) Preparation and storage of mixed fruit juice spiced beverage Ph.D. thesis, Indian Agricultural Research Institute, New Delhi.

11. Singh K, Mathur PB (1983) Studies in the cold storage of cashew apple. Indian J Hort 10: $115-121$.

12. Das RC, Dash J (1967) The effect of wax emulsion, 2, 4-D and 2, 4, 5-T on the storage behavior of musambi fruits. Proc. Intl. Symp. Sub-trop. and Trop Horti, New Delhi.

13. Sethi V, Anand JC, Sexana SK (1980) Kinnow orange in juice and beverage making. Indian J Hort 28: 13-15.

14. Khurdiya DS, Anand JC (1981) Effect of storage temperature on quality of phalsa beverage. J Food Sci \& Technol 18: 16-20.

15. Pandey AK, Singh IS (1999) Studies on preparation and preservation of guava ready-to-serve beverage. Indian J Hort 56: 130-132.

16. AOAC (1980) Office Methods of Analysis of the Association of Official Agricultural Chemist $12^{\text {th }}$ Ed., Washington, D.C. 